\title{
A framework for the classification Chilean terrestrial ecosystems as a tool for achieving global conservation targets
}

\author{
Karina Martínez-Tilleria ${ }^{1,3} \cdot$ Mariela Núñez-Ávila ${ }^{2}$ (D) \\ Carolina A. León $n^{2,5}$ - Patricio Pliscoff ${ }^{3}$ - Francisco A. Squeo ${ }^{1,4}$. \\ Juan J. Armesto ${ }^{2,3,6}$
}

Received: 21 September 2016/Revised: 27 April 2017/Accepted: 13 June 2017/

Published online: 21 June 2017

(C) The Author(s) 2017. This article is an open access publication

\begin{abstract}
Countries that are signatories of the Convention of Biological Diversity are committed to the goal of protecting $17 \%$ of their natural ecosystems by 2020 . The lack of an up-to-date, operational classification and cartography of regional ecosystems seriously limits the assessment of progress towards this goal. Here, we present a broad ecosystem framework, which combines land use, functional traits of dominant plant species, and climatic factors for the classification of terrestrial ecosystems and apply this framework to classify Chilean terrestrial ecosystems. This new classification is consistent with the recently proposed IUCN framework to assess ecosystem conservation status. Using this framework, we identified and described 30 Chilean terrestrial ecosystems, including land units of natural and anthropogenic origin. We also provide a cartographic representation of ecosystems for land planning purposes and an overall assessment of their conservation status. We evaluated the representation of the 30 ecosystems in the Chilean National System of Protected Areas (NSPA) and in Private Protected Areas (PPA), identifying 15
\end{abstract}

Communicated by Jefferson Prado.

Electronic supplementary material The online version of this article (doi:10.1007/s10531-017-1393-x) contains supplementary material, which is available to authorized users.

Mariela Núñez-Ávila

mnunezavila@gmail.com

1 Departamento de Biología, Facultad de Ciencias, Universidad de La Serena, Raúl Bitrán 1305, La Serena, Chile

2 Instituto de Ecología y Biodiversidad (IEB), Universidad de Chile, Santiago, Chile

3 Departamento de Ecología, Facultad de Ciencias Biológicas, Pontificia Universidad Católica de Chile, Casilla 114-D, Santiago, Chile

4 Centro de Estudios Avanzados en Zonas Áridas (CEAZA), Raúl Bitrán 1305, La Serena, Chile

5 Centro de Investigación en Recursos Naturales y Sustentabilidad, Universidad Bernardo O Higgins, Fábrica 1990, segundo piso, Santiago, Chile

6 Cary Institute of Ecosystem Studies, Millbrook, NY, USA 
ecosystems underrepresented (below the 17\% target) in the NSPA, in contrast to only 11 when the area of NSPA+PPA was considered. The proposed classification can be broadly applicable to assess the conservation status of ecosystems elsewhere, using similar conceptual and methodological tools. The development of functional ecosystem classifications for different countries must be encouraged to facilitate monitoring of global conservation targets.

Keywords Ecosystem approach · Biodiversity conservation · Functional traits $\cdot$ Protected areas

\section{Introduction}

Following Chapin et al. (2012), an ecosystem can be defined as a spatially explicit area of land, where exchanges of matter and energy among organisms (including humans) and between organisms and their physical environment take place. Ecosystems are thus defined by internal nutrient cycles as well as by energy and matter exchanges with their surroundings. An ecosystem approach is increasingly relevant to assess the responses of the biota to global climate change, the ecological consequences of altered biogeochemical processes, and the functional impacts of biodiversity losses (Hassan et al. 2005; Cardinale et al. 2012). The second half of the 20th century has seen the growth of human impacts to unprecedented levels in the history of the planet (Steffen et al. 2011; Corlett 2015), causing major disruptions of the distribution of species and ecosystems (Traill et al. 2010; Dirzo et al. 2014). These impacts imply a large "extinction debt" (Wearn et al. 2012), with gloomy consequences for the provision of ecosystem services to humanity. Conservation measures based on improved knowledge of ecosystems are urgently needed by governments to address the impending threats of biodiversity loss (Wilson et al. 2006; Kujala et al. 2013; CONAMA 2005). Because no universally accepted global taxonomy of ecosystems yet exists (Keith et al. 2013), a general framework for the classification and assessment of regional ecosystems must be the first step for a repeatable assessment of their global conservation status. Here, we contribute to this goal by developing such a framework for ecosystem classification along with an example of its application to identify and assess the status of terrestrial ecosystems in Chile.

Countries that are signatories of the Convention of Biological Diversity (CBD) are committed to improve the representation of national ecosystems in their Parks and Reserves systems, with a generally accepted target of $17 \%$ of the remaining area of each major terrestrial ecosystem by the year 2020 (CBD 2010). For many countries, the lack of a functional classification of national ecosystems can be a serious drawback in this process. Chile, and other Latin American countries, which harbor globally significant biodiversity hotspots (Myers et al. 2000) commonly use classifications of natural communities constructed primarily with a main focus on vascular plant assemblages (particularly the woody flora), considering broad patterns of variation across macro-regions or biomes (e.g., Gajardo 1994). Other classifications of land units use landscape features, knowledge of vegetation dynamics, or historical records to expand the scope of floristic classifications (e.g., Acosta et al. 2005; Mucina 2013; Van Sickle and Hughes 2000). However, up to now, few national classifications have addressed the need for applying an ecosystem framework to identify natural land units (Currie 2011; Chapin et al. 2012). 
In this paper, we propose a general methodology based on functional criteria to identify terrestrial ecosystems, and apply this methodology to the classification of terrestrial ecosystems of Chile, a country signatory of the CBD, which includes an extensive global biodiversity hotspot (Myers et al. 2000). This classification can be expressed on a cartography that can foster biodiversity conservation, allow the monitoring future ecosystem transitions, and support landscape planning for ecosystem service provision. We evaluate the representation of these ecosystems in the Chilean National System of Protected Areas (NSPA) and Private Protected Areas (PPA) and discuss what is needed to achieve the minimum conservation goal of $17 \%$ of underrepresented natural ecosystems.

\section{Framework for ecosystem classification}

Ecosystem-scale responses to climate change and other global environmental impacts (e.g., atmospheric deposition of nitrogen) can be better understood by attention to dominant functional types (Chapin et al. 1996). Therefore, ecosystem assessments require key biodiversity-related factors that influence the transfer of energy and materials within and across the boundaries of major ecosystems. This information needs to be associated with distinctive spatial units of land that can be mapped at spatial scales that are useful to managers and decision makers. Such exercise remains a major methodological challenge, as information on functional traits is deficient for many ecosystems. Consequently, we may be forced to base ecosystem classifications on sparse functional data, which must be superimposed on land cover charts, derived from existing aerial photos or satellite images taken with arbitrary resolution (e.g., CONAF et al. 1999; Zhao et al. 2016).

Classification for terrestrial natural systems are often based on vegetation cover maps of each country or region, coupled with empirical or extrapolated information on plant communities assemblages, climate and topography (e.g., Devillers et al. 1991; Meidinger and Pojar 1991; Devillers and Devillers-Terschuren 1996; Comer et al. 2003; Cowling et al. 2003; Benson 2006; Josse et al. 2007; NatureServe 2003; Luebert and Pliscoff 2006). We propose here an alternative methodology for natural systems that advances the functional classification of terrestrial ecosystems by adding biological information on functional traits of primary producers to the layers generally available in Geographic Information Systems. The new methodology identifies dominant "functional types" based on species traits of primary producers that influence energy and matter transfer, as fundamental ecosystem properties. In practical terms, for each landscape unit defined by natural land cover, we propose to identify the contrasting set of morphological-structuralphysiological traits shared by co-occurring species (or "functional groups"), which regulate elemental fluxes among plants, soil, water and atmosphere (Kattge et al. 2011). A functional group contains species from diverse taxonomic categories and phylogenetic origins, and is not necessarily coincident with previously defined taxonomic units or dominant plant associations (Díaz and Cabido 1997).

The adoption of the functional ecosystem criteria proposed here does not conflict with other classifications based on taxonomic assemblages or floristic units, which can be related to altitudinal zonation or prevailing climate (e.g., biomes). A classification of ecosystems based on functional types should expand on other classification systems supporting specific management or planning goals. An analysis of the correspondence between different classification systems (e.g., taxonomic units versus ecosystem types) can later assist managers in selecting the most appropriate framework for their objectives. Using an 
ecosystem perspective can also assist managers in evaluating the present status and future threats to ecosystem services, particularly with reference to the identification of sensitive ecological processes and functionally relevant biodiversity components (Keith et al. 2013).

\section{Anthropogenic land use/cover units}

In addition to identifying the present native ecosystems of a given region based on the criteria outlined above, we need to consider the major landscape transformations associated with human activities. In today's world, many ecosystems have been changed drastically into novel species assemblages that include many species exotic to the area (Hobbs et al. 2006, 2009), or new pathways of energy and matter transfer associated with human needs (e.g., urban ecosystems). Such transformations are represented by the use of the terms 'novel ecosystems' or anthropogenic systems, as well as by land use categories (e.g., agroforestry systems or grazing pastures). In our analysis, we have first separated these human-dominated ecosystems (Vitousek et al. 1997; Noble and Dirzo 1997) from native ecosystems. Distinction of anthropogenic ecosystems can be based on land use/cover maps. Generally such cartographic information for each country is available from National Inventories such as corine land cover (EEA 2006). It is well known that ecosystems managed by humans are rapidly changing, they greatly alter the flow paths of nutrients and energy in the landscape, and in some cases may harbor some valuable remnants of biodiversity. These are all processes that we need to keep monitoring. The location and extent of anthropogenic ecosystems constraints our delimitation of natural ecosystems, but we excluded them from the analysis based on functional traits of dominant species because their persistence is largely dependent on inputs of energy, water, and nutrients from humans.

\section{Methods}

\section{Criteria used for the classification of ecosystems}

Criteria used to build an ecosystem classification are constrained by available information on land cover/land use types and knowledge of functional traits of dominant land plants for the region of interest. Plants represent the primary producers in nearly all-terrestrial ecosystems and carbon assimilated by their photosynthetic tissues is the main source of matter and energy for the entire trophic web. Accordingly, functional leaf traits of dominant species in terms of above ground biomass were used to infer functional types that can influence carbon, nutrient, and energy exchanges. Modulating factors related to topography (elevation) and climate (temperature and precipitation) can be used when necessary to distinguish areas dominated by similar functional groups, but where ecosystem properties (productivity, diversity, and biomass) were regulated by differences in climate, nutrient limitation or extreme conditions.

As explained earlier, we propose to begin the classification of terrestrial ecosystems by identifying major land cover types using eight criteria with their corresponding categories (Table 1).

Criterion A distinguishes whether current land cover is with or without vegetation cover, freshwater bodies, or human-dominated ecosystems (Table 1). Within each of these 
Table 1 Description of major typological criteria used for ecosystem classification and mapping

\begin{tabular}{ll}
\hline Criteria & Description of criterion \\
\hline A. Land cover type & $\begin{array}{l}\text { This criterion distinguishes land units } \\
\text { depending on the presence of vegetation } \\
\text { cover, level of water saturation and } \\
\text { human-dominance }\end{array}$
\end{tabular}

B. Land use type Defined by human land use as primary driver of energy and matter exchanges.

Ecosystems are often managed, and hence they lack most of historical native plant cover

C. Water saturation of soil

D. Vegetation cover (proportion of land surface)

E. Dominant life form

F. Functional leaf traits

\section{G. Climate modulators}

H. Ecosystems in
extreme
environments

This category comprises freshwater wetlands, classified by water saturation of soil

Ecosystems with or without native plant cover. The $10 \%$ cover limit allows the distinction of ecosystems predominantly shaped by vegetation dynamics rather than physical factors

Ecosystems dominated by vegetation with contrasting growth habits or life forms. Dominance is referred to the control of energy and matter transfers

Ecosystems dominated by functional types defined by contrasting leaf traits, such as leaf size, leaf duration and leaf type. Leaf traits influence the circulation of nutrients within the ecosystems and reflect climatevegetation relationships

Distinctions are based on how water and temperature influence ecosystem processes. Finer distinctions could be made here when necessary, depending on each country or region

Ecosystems with less than $10 \%$ plant cover are separated depending on whether production is strongly nutrient-limited (e.g., $\mathrm{P}$ or $\mathrm{N}$ in young rock substrates), or limited by extreme temperatures (areas above treeline) or water deficit (deserts)
Categories defining ecosystem types

A.1. Terrestrial systems with or without vegetation cover

A.2. Freshwater bodies

A.3. Anthropogenic systems

B.1. Ecosystems dominated by exotic plant cover

\section{B.2. Urban ecosystems}

B.3. Industrial and mining systems

B.4. Agro-pastoral systems

B.5. Commercial forestry plantations

C.1. Telmatic ecosystem

C.2. Aquatic ecosystem

D.1. Vegetation cover $>10 \%$

D.2. Vegetation cover $<10 \%$

D.3. Land without vegetation cover

E.1. Herbaceous cover predominant

E.2. Succulent-dominated

E.3. Scrublands

E.4. Tree-dominated (forest)

F.1. Evergreen

F.2. Deciduous

F.3 Microphyllous

F.4. Macrophyllous

F.5. Broad leaved

F.6. Conifer

F.7. Drought-deciduous

F.8. Winter-deciduous

G.1. Desert

G.2. Mediterranean

G.3. Warm-temperate

G.4. Cold-temperate

G 5. Sub-Antarctic

H.1. Nutrient-limited

H.2. Water limited

H.3. Temperature limited

Land units were first defined by the primary criteria listed in $A$ (land cover), and subsequently further subdivided hierarchically into ecosystem types, based on criteria $B$ (anthropogenic land use), $C$ (water saturation of soils), $D$ (proportion of land covered by vegetation), $E$ (dominant life form), $F$ (functional leaf traits of dominant species), $G$ (modulating climate factors), and finally $H$ (extreme environments). See further explanation of categories see supplementary materials 
broad land cover/use categories, we made subsequent distinctions in our framework (Table 1) using secondary criteria. Anthropogenic land units were separated on the basis of the type of human activity driving energy and matter exchanges (criterion B). Our criterion $B$ refers only to ecosystems associated with anthropogenic land cover (Table 1), hence lacking most of the historical native plant cover. We also include here novel ecosystems originated by the spontaneous or deliberate massive establishment of exotic species, without possibility of returning to the original historical species composition and ecosystem structure without costly human intervention (Hobbs et al. 2006).

Criterion $C$ comprises freshwater wetlands, depending on the water saturation of soil (Table 1). We recognized two main types of wetland ecosystems (aquatic and telmatic), which represent the broad categories of shallow water and semi-terrestrial wetland (Wheeler 1999; Wheeler and Proctor 2000). For reasons of simplicity, we have ignored in this classification the salt marshes, occurring at the interface between terrestrial and marine environments, but they could be easily incorporated in the classification system using additional categories.

Criterion $D$ distinguishes between ecosystems with or without presence of native plant cover. If vegetation cover is present, we further distinguish ecosystems depending on whether plant cover is normally greater or less than $10 \%$ (Table 1 ). The $10 \%$ cover cutoff point could be estimated from the average plant cover among years. We chose this $10 \%$ cover limit because it allows the distinction of ecosystems predominantly shaped by vegetation dynamics (cover $>10 \%$ ), influencing ecosystem production, structure, and biodiversity, from ecosystems where geo-physical processes dominate the energy and matter exchanges (salt flats, coastal sand dunes, vegetation above treeline). In most ecosystems the influence of vegetation cover on ecosystem process in not lineal, but increases exponentially beyond threshold level, which can be a low cover value (Scheffer 2009 ). Some ecosystems in the category $<10 \%$ cover may represent young stages of soil development on new substrates, such as dune fields, volcanic debris, or areas where productivity is restricted by extreme conditions (e.g., temperatures above treeline) or lack of rainfall (e.g., deserts with ephemeral plant cover).

Criterion $E$ differentiates among ecosystems with $>10 \%$ vegetation cover. Distinctions here are based on the dominance by vegetation with contrasting growth habits or life forms that control energy and matter transfers (Table 1). Differences in growth habits or life forms are relevant regarding carbon and nutrient fluxes because of striking differences in life spans of perennial organs (related to carbon assimilation and storage).

In our framework, scrublands (E3) and tree-dominated (E4) ecosystems (Table 1), with predominance of woody life forms, we further subdivided ecosystems based on the presence of different functional groups (criterion $F$ ), defined by leaf traits, such as leaf size, leaf duration and leaf type (Table 1). These simple characters are known to influence the circulation of nutrients within the ecosystems and reflect plant-climate relationships (Duckworth et al. 2000; Peppe et al. 2011). It has also been shown that foliage element stoichiometry (e.g., carbon/nitrogen ratio) can regulate litter decomposition and nutrient recycling processes (Pérez et al. 1998), and that carbon and water fluxes are strongly dependent on leaf duration (e.g., evergreen versus deciduous leaves), size (leaf area index), type (conifer versus angiosperm), and degree of sclerophylly. Therefore, we justify our rather narrow focus on foliage characters for functional type definitions because leaves are the sensitive regulators of carbon and energy uptake in ecosystems.

Different types of scrubland ecosystems are distinguished by the dominance of shrubs with perennial foliage and contrasting leaf size (microphyllous, small-leaved, or macrophyllous, broad-leaved), which occur in montane and desert environments, or by drought- 
deciduous shrubs found on xeric slopes in Mediterranean-climate regions (Armesto et al. 2007). In the case of forests, ecosystems were classified based on major leaf traits of canopy dominants in a similar way as scrublands (Table 1), distinguishing first between evergreen and deciduous canopies. For scrubland and forest ecosystems dominated by species with similar functional traits, we used climate modulators as secondary criteria (criterion $G$ ) for ecosystem distinctions. These were associated with desert, mediterranean, warm temperate, and cold temperate ecosystems (Table 1). Finer distinctions could be made here when necessary, depending on the climatic zones in each country or region.

Finally, ecosystems in extreme environments (criterion $H$ ), with less than $10 \%$ plant cover, are separated into those where production is strongly nutrient-limited (e.g., young rocky substrates), and those where production is limited by extreme climate, mainly low temperatures (above treeline) and lack of water (deserts).

\section{Application of the above criteria to Chilean ecosystems}

We developed a classification of ecosystems for the entire area of continental Chile. In the case of Chile, our ecosystems were based on the information provided by the existing the National Land Use Inventory (CONAF et al. 1999).

The National Land Use Inventory was initiated in 1993 by the Chilean Forest Service (Corporación Nacional Forestal, CONAF). This inventory identified land cover units presented as a cartographic product (similar to the CORINE Project), initially at a scale of $1: 100,000$. This database (sit.conaf.cl) is available for entire country and is updated about every 10 years (Supplementary Material B).

The typology for the classification of land use/cover units used by the national inventory is based on the methods developed by the Louis Emberger Center for Phytosociological and Ecological Studies (CEPE/CNRS of Montpellier, France), known as the Land Use Chart (Etienne and Prado 1982). The main types of land use/cover defined in this analysis are: urban and industrial areas, agricultural land, grasslands and shrublands, forest plantations, native forest, mixed forest, wetlands, and areas devoid of vegetation, snow, glaciers and water bodies.

The scale of resolution of our ecosystem assessment was limited to the scale of resolution of the National Land Use Inventory (CONAF et al. 1999). When available, we used regional updates of the survey that have greater resolution (see Supplementary Material B). The existing cartography was then adjusted to the WGS84 coordinate reference system, using Universal Transversal Mercator (UTMs) projections for the latitude $19^{\circ} \mathrm{S}$. We produced national and regional cartographies with their respective information layers (.shp) using the program ArcGIS 10.

To refine the distinction of land units with natural vegetation cover, we considered a newly revised classification of plant communities for Chile that provided detailed information on the assemblages for each land unit (Squeo et al. 2003). We selected the three main dominant species for each land cover unit and classified them according to the categories described in Table 1. These categories were used as filters for separating the different ecosystems (Table 2).

The list of natural and anthropogenic ecosystems defined using these criteria, was later validated through a process of consultation with regional experts from national and International universities (Supplementary material C), using electronic mail surveys and specially designed workshops. Expert opinions were used to refine or correct the classification system and their cartographic representation. 
Table 2 Land area and proportion of the country's land area estimated for 30 Chilean ecosystems defined by the major criteria given in Table 1

\begin{tabular}{|c|c|c|c|c|c|c|c|}
\hline \multirow[t]{2}{*}{ Ecosystem } & \multirow{2}{*}{$\begin{array}{l}\text { Criteria for } \\
\text { defining ecosystem }\end{array}$} & \multicolumn{2}{|c|}{ Land cover } & \multicolumn{2}{|l|}{ NSPA } & \multicolumn{2}{|c|}{$\mathrm{NSPA}+\mathrm{PPA}$} \\
\hline & & $\mathrm{km}^{2}$ & $\%$ & $\mathrm{~km}^{2}$ & $\%$ & $\mathrm{~km}^{2}$ & $\%$ \\
\hline High-Andean steppe & A1-D1-E1-G1 & 21,062 & 2.8 & 4165 & 19.8 & 4168 & 19.8 \\
\hline Central Chilean Andean steppe* & A1-D1-E1-G2 & 3986 & 0.5 & 357 & 8.9 & 381 & 9.5 \\
\hline Patagonian steppe* & A1-D1-E1-G3 & 19,921 & 2.6 & 958 & 4.8 & 1372 & 6.9 \\
\hline $\begin{array}{l}\text { Ecosystems dominated by } \\
\text { succulents* }\end{array}$ & A1-D1-E2 & 1810 & 0.2 & 70 & 3.9 & 70 & 3.9 \\
\hline $\begin{array}{l}\text { Evergreen scrub with } \\
\text { microphyllous leaves* }\end{array}$ & A1-D1-E3-F3 & 88,927 & 11.7 & 3246 & 3.7 & 5324 & 6.0 \\
\hline $\begin{array}{l}\text { Evergreen scrub with } \\
\text { macrophyllous leaves* }\end{array}$ & A1-D1-E3-F4 & 10,205 & 1.3 & 157 & 1.5 & 398 & 3.9 \\
\hline Drought-deciduous scrub* & A1-D1-E3-F7-G2 & 21,376 & 2.8 & 310 & 1.5 & 501 & 2.3 \\
\hline $\begin{array}{l}\text { Broad-leaved sclerophyllous } \\
\text { forest ecosystem* }\end{array}$ & A1-D1-E4-F5-G2 & 12,826 & 1.7 & 147 & 1.1 & 265 & 2.1 \\
\hline $\begin{array}{l}\text { Broad-leaved warm-temperate } \\
\text { forest ecosystem** }\end{array}$ & A1-D1-E4-F5-G3 & 23,601 & 3.1 & 2740 & 11.6 & 4059 & 17.2 \\
\hline $\begin{array}{l}\text { Broad-leaved cold-temperate } \\
\text { forest ecosystem }\end{array}$ & A1-D1-E4-F5-G4 & 39,343 & 5.2 & 14,837 & 37.7 & 17,010 & 43.2 \\
\hline $\begin{array}{l}\text { Broad-leaved sub-Antarctic } \\
\text { forest ecosystem }\end{array}$ & A1-D1-E4-F5-G5 & 24,749 & 3.3 & 8806 & 35.6 & 10,052 & 40.6 \\
\hline $\begin{array}{l}\text { Conifer-dominated forest } \\
\text { ecosystems }\end{array}$ & A1-D1-E4-F6 & 3424 & 0.4 & 1550 & 45.3 & 1732 & 50.6 \\
\hline $\begin{array}{l}\text { Drought-deciduous desert } \\
\text { woodland ecosystem }\end{array}$ & A1-D1-E4-F7-G1 & 1180 & 0.1 & 250 & 21.2 & 250 & 21.2 \\
\hline $\begin{array}{l}\text { Winter-deciduous warm- } \\
\text { temperate forest ecosystem* }\end{array}$ & A1-D1-E4-F8-G3 & 17,872 & 2.4 & 541 & 3.0 & 871 & 4.9 \\
\hline $\begin{array}{l}\text { Winter-deciduous cold-temperate } \\
\text { forest ecosystem }\end{array}$ & A1-D1-E4-F8-G4 & 33,033 & 4.4 & 5521 & 16.7 & 7637 & 23.1 \\
\hline Salt flat ecosystem* & $\begin{array}{l}\text { A1-D2-H1-H2- } \\
\text { H3 }\end{array}$ & 8363 & 1.1 & 617 & 7.4 & 678 & 8.1 \\
\hline Sand dune ecosystems* & A1-D2-H1 & 1942 & 0.3 & 47 & 2.4 & 58 & 3.0 \\
\hline $\begin{array}{l}\text { Ecosystems on lava flows, } \\
\text { volcanic rocks and ash }\end{array}$ & A1-D3-H1 & 1475 & 0.2 & 521 & 35.3 & 530 & 35.9 \\
\hline Low-elevation desert ecosystem* & $\mathrm{A} 1-\mathrm{D} 2-\mathrm{H} 2$ & 12,733 & 1.7 & 0.0 & 0.0 & 503 & 4.0 \\
\hline $\begin{array}{l}\text { Andean desert ecosystems above } \\
\text { treeline* }\end{array}$ & $\mathrm{A} 1-\mathrm{D} 2-\mathrm{H} 3$ & 42,467 & 5.6 & 2720 & 6.4 & 3381 & 8.0 \\
\hline Absolute desert* & $\mathrm{A} 1-\mathrm{D} 3-\mathrm{H} 2$ & 139,555 & 18.5 & 2963 & 2.1 & 2972 & 2.1 \\
\hline Glaciers & A1-D3-H3 & 26,889 & 3.6 & 18,118 & 67.4 & 19,382 & 72.1 \\
\hline Telmatic ecosystems & $\mathrm{A} 2-\mathrm{C} 1$ & 45,162 & 5.9 & 29,117 & 64.5 & 29,517 & 65.4 \\
\hline Aquatic ecosystems & $\mathrm{A} 2-\mathrm{C} 2$ & 9043 & 1.2 & 2155 & 23.8 & 2262 & 25.0 \\
\hline $\begin{array}{l}\text { Ecosystems dominated by } \\
\text { invasive species } * * *\end{array}$ & A3-B1 & 1052 & 0.1 & - & - & - & - \\
\hline Urban ecosystems $* * *$ & A3-B2 & 2036 & 0.3 & - & - & - & - \\
\hline Industrial-Mining complexes*** & A3-B3 & 163 & 0.02 & - & - & - & - \\
\hline $\begin{array}{l}\text { Intensive-use agro-pastoral } \\
\text { ecosystems } * * *\end{array}$ & A3-B4 & 52,837 & 6.9 & - & - & - & - \\
\hline Conifer plantations*** & A3-B5-F1 & 21,401 & 2.8 & - & - & - & - \\
\hline
\end{tabular}


Table 2 continued

\begin{tabular}{|c|c|c|c|c|c|c|c|}
\hline \multirow[t]{2}{*}{ Ecosystem } & \multirow{2}{*}{$\begin{array}{l}\text { Criteria for } \\
\text { defining ecosystem }\end{array}$} & \multicolumn{2}{|c|}{ Land cover } & \multicolumn{2}{|c|}{ NSPA } & \multicolumn{2}{|c|}{$\mathrm{NSPA}+\mathrm{PPA}$} \\
\hline & & $\mathrm{km}^{2}$ & $\%$ & $\mathrm{~km}^{2}$ & $\%$ & $\mathrm{~km}^{2}$ & $\%$ \\
\hline Broad-leaved plantations*** & A3-B5-F2 & 4212 & 0.6 & - & - & - & - \\
\hline
\end{tabular}

Representativeness and gap analysis for natural ecosystems were calculated under two conservation scenarios: The target of $17 \%$ protected for each ecosystem was considered. Scenario 1 is the percentage of each ecosystem protected within the National System of Protected Areas (NSPA), and Scenario 2 is the percentage of each ecosystem protected within NSPA plus Private Protected Areas (PPA)

* Ecosystem does not meet the target of $17 \%$ protection in scenario 1

** Ecosystem meets the target of $17 \%$ protection after adding PPA

*** Anthropogenic ecosystems

\section{Conservation scenarios}

To analyze the proportion of ecosystems under protection, we calculated the area of each ecosystems represented in: (1) The National System of Protected Areas $\left(147.280 \mathrm{~km}^{2}\right)$, i.e. public parks and reserves, and (2) NSPA plus Private Protected Areas $\left(17.065 \mathrm{~km}^{2}\right)$ in Chile. The source for the areas and distributions of NSPA and PPA were CONAF and Núñez-Ávila and Corcuera (2014), respectively. We assessed the conservation target of $17 \%$ of the area of each ecosystem.

\section{Results}

The application of the proposed framework, based on mapping vegetation life forms and functional leaf traits over a previous inventory of land use/cover units (CONAF et al. 1999), allowed the recognition of 30 different terrestrial ecosystems in mainland Chile (Table 2; Fig. 1). Six ecosystems represent land use/cover types originated in recent decades due to human intervention, also defined as anthropogenic ecosystems. We also recognized two broad types of wetlands, 15 terrestrial ecosystems with $>10 \%$ native vegetation cover, five ecosystems with $<10 \%$ native vegetation cover, and finally two ecosystems lacking significant macroscopic plant cover. Ecosystem names given in the list of Chilean ecosystems (Table 2) refer to the principal functional characters (physiognomically-dominant life form or leaf type), or to differences in specific geographic location and general climate of the unit defined. Some names followed traditional denominations given by specialists, but nomenclatural aspects were not dealt with here. Additional ecological, environmental, distributional, and species composition data characterizing each ecosystem listed in Table 2 and a brief assessment of their conservation status are provided as Supplementary Material. Ecosystem descriptions follow Keith et al. (2013), who argued that a clear description of the functional units in the landscape represents an important first step for a repeatable assessment process.

\section{Areal extent of each ecosystem}

Ecosystems dominated by native vegetation cover represent $76 \%$ of Chile's mainland area, including steppe, scrublands and forests (Table 2). Because of the lack of detailed data on ecosystem-level processes and their dependence on functional groups, ecosystem 


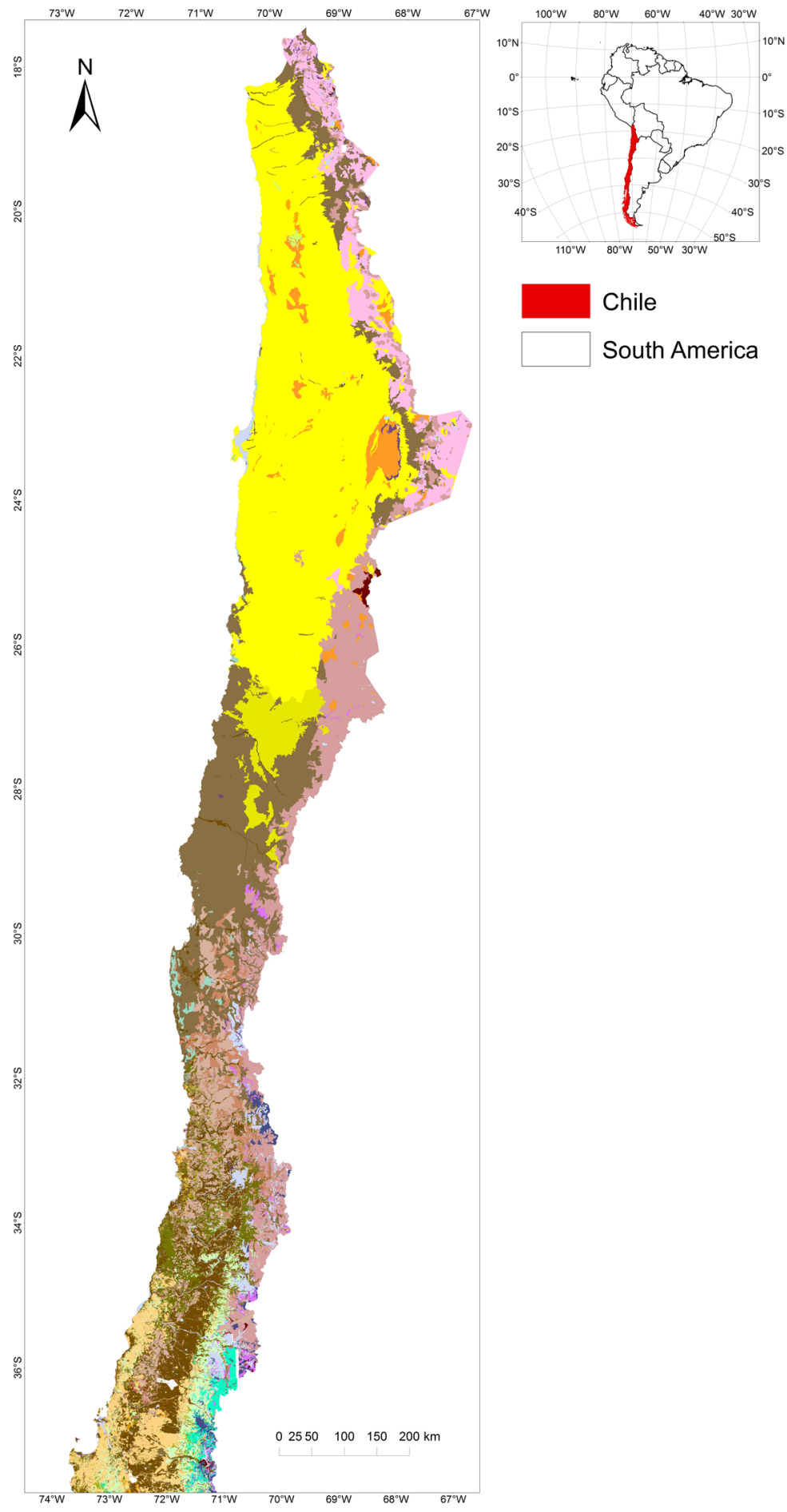


4Fig. 1 Cartography of the 30 Chilean terrestrial ecosystems resulting from applying the criteria and categories proposed in this paper. Ecosystems dominated by native vegetation cover represent $76 \%$ of Chile's mainland area. A desert ecosystem occupies about $17 \%$ of Chile's mainland area. About $12 \%$ of the Chilean territory has been transformed into ecosystems of anthropogenic origin, which are also mapped together with natural ecosystems. Central Chile, the richest biodiversity area in the country, also displays a high diversity of ecosystems between $30^{\circ}$ and $40^{\circ} \mathrm{S}$. Small unidentified areas are sections that were unavailable in aerial photographs

distinctions made here are by necessity coarse, but it will be possible to refine them as new information becomes available. About $12 \%$ of the Chilean territory has been transformed into ecosystems of anthropogenic origin (Table 2), where humans are the main drivers of ecosystem processes and management dominates the transfers of matter and energy. We included in this category landscapes covered by spontaneously spreading exotic species, which sometimes constitute mixed ecosystems with native species. These ecosystems may expand in response to increasing disturbance frequency (e.g., fire). Such ecosystems, characterized by new combinations of introduced and native species that arise through human action have been labeled "novel" or "emerging" ecosystems (Hobbs et al. 2006). According to our assessment they currently occupy $0.15 \%$ of the country.

Wetland ecosystems cover $8 \%$ of the continental area. Despite their limited extent, these ecosystems have a disproportionately high regional importance for water supply and storage (Cohen et al. 2016). Along with glacier ecosystems, which cover $3.7 \%$ of the land area, they represent the main source water for human use. Based on these figures, ecosystems responsible for most freshwater storage represent $4.5 \%$ of continental Chile. Monitoring the fate of these wetland ecosystems in western South America will be especially relevant, considering climate change and growing water demands (Vörösmarty and Sahagian 2000). A finer classification of freshwater ecosystems, including functionally significant riparian environments will await further analysis using higher resolution.

A high proportion of mainland Chile is occupied by an absolute desert (17\%). The hyperarid Atacama Desert occupies the coast and mid elevations of northern Chile where rainfall is nearly absent (Arroyo et al. 1988). The desert ecosystem is socio-economically relevant because of the presence of copper mining and other mineral deposits and the presence of significant reserves of underground water used by both the mining industry and coastal cities. Underground water reserves in the Atacama Desert are replenished by rainfall cycles that occur at millennial time scales (Gayó et al. 2012) and present consumption levels threaten their continuous supply. Semiarid ecosystems, including scrubland and Cactaceae-dominated vegetation, taken together occupy nearly $15 \%$ of Chile's mainland. Despite their extent, arid and semiarid ecosystems are generally ignored in calculations of global carbon uptake and storage (Poulter et al. 2014), an uncertainty that must be addressed through ecosystem monitoring. The conservation status of species-rich semiarid ecosystems (Squeo et al. 2001, 2008) is precarious. Recent losses of scrubland area are due to the expansion of irrigation farming into drier areas (Schulz et al. 2010). Semiarid ecosystems are poorly represented in the public system of protected areas (Squeo et al. 2012).

Scrublands are the most diverse and widely distributed ecosystems in Chile, including drought-deciduous and evergreen scrubland, characteristic of semiarid and Mediterranean Chile, as well as Andean and Patagonian steppes, both dominated by evergreen shrubs (Table 2). Steppes have sparse shrub cover and are associated with cooler temperatures (due to elevation or latitudinal effects). The presence of dense populations of tussock grasses and caespitose plants in the understory of the sparse scrubland is a diagnostic 


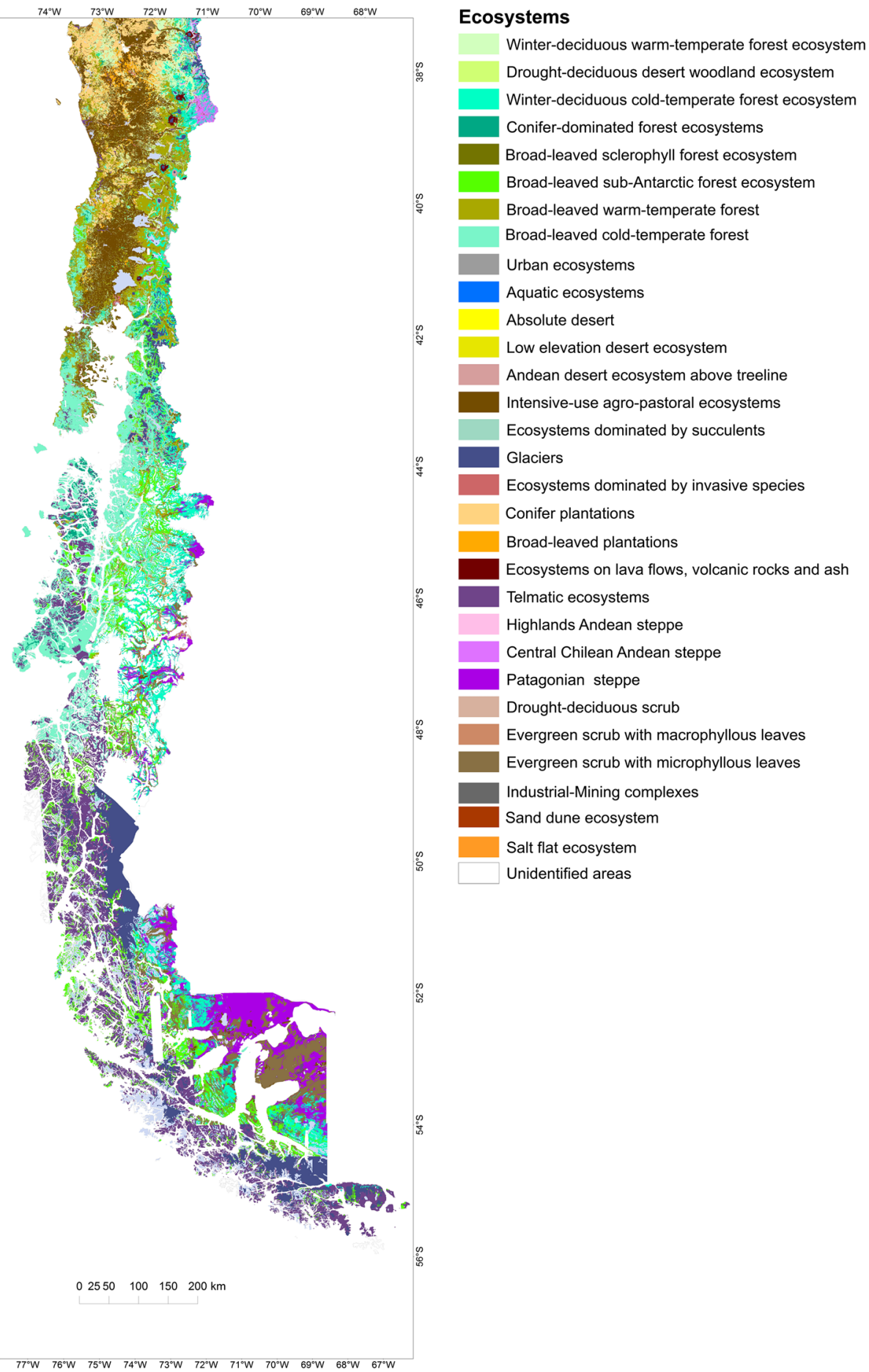

Fig. 1 continued 
character of steppe ecosystems (Pisano 1974; Arroyo et al. 1993). In total, six types of scrubland ecosystems are recognized in this classification, which differ in the main leaf traits of dominant shrubs as well as in their altitudinal or latitudinal distribution. These types differ importantly in the main factors limiting nutrient cycles, namely, temperature, drought, or foliage quality (Austin and Vivanco 2006; Speziale et al. 2010). Because ecosystem functions of scrubland have been less studied than forests, it is possible that we could distinguish a higher number of scrubland types in semiarid and montane regions after further study. The sclerophyllous scrubland of central Chile, or Chilean matorral, is probably the most endangered ecosystem type in mainland Chile, because of historical reduction in extent (Holmgren et al. 2000; Armesto et al. 2007, 2010), despite being biologically one of the richest ecosystems in the country (Rundel 1981; Arroyo et al. 1993; Cowling et al. 2005).

Across a broad range of elevations from $34^{\circ}$ to $56^{\circ} \mathrm{S}$ (Arroyo et al. 1993; Luebert and Pliscoff 2006; Armesto et al. 2007), forests are the most important and variable ecosystems. We distinguished eight different forest ecosystem types (Table 2), depending on contrasting physiognomies and differences in leaf traits (size, duration, and type) of tree species, the dominance by conifers versus angiosperms, or the presence of evergreen versus deciduous foliage. Along the latitudinal gradient, there are substantive differences in climate modulators among warm-temperate, cool-temperate, and sub-Antarctic forest ecosystems, which can be dominated by evergreen or deciduous tree species (Table 2). Ecosystems with a fully deciduous tree canopy (Nothofagus-dominated) are only found in sub-Antarctic ecosystems and form the timberline up to $35^{\circ} \mathrm{S}$ along the temperate Andes (Hildebrand-Vogel et al. 1990; Cuevas 2000).

When combining the extension of the eight forest ecosystem types defined here (Table 2), from Mediterranean to sub-Antarctic latitudes, ecosystems dominated by trees represent nearly $20 \%$ of the Chilean mainland. The area of nearly $150,000 \mathrm{~km}^{2}$ of forested ecosystems has significant ecological and economic importance because of the provision of multiple resources to native people (Smith-Ramírez 1996), carbon storage (Armesto et al. 2009), and ecosystem services, especially the regulation water supplies for human and agricultural use (Lara et al. 2009). In addition, because of their structural complexity, forest ecosystems provide habitats for an outstanding biodiversity, including animal pollinators associated with a diverse array of flowering trees (Smith-Ramírez et al. 2005; RamosJiliberto et al. 2009) and high biomass loads of a rich assemblage of epiphytes and vines (Díaz et al. 2010).

Among forest ecosystem types, the smallest area corresponds to ecosystems dominated by conifers $(0.5 \%$ of Chile's land area), which have a regionally restricted geographic distribution. Most conifer-dominated forest ecosystems are presently limited to high mountain areas, or water saturated, poorly drained, lowland soils in temperate latitudes. They also occupy the drier ecotone between forest and steppe in the eastern side of the Andes (Veblen et al. 1995).

Finally, small areas of forests exist in the lowland Atacama Desert, where the phreatophyte Propopis tamarugo is the only tree present, as well as above $3500 \mathrm{~m}$ on the dry slopes of Andean volcanoes in northern Chile, where the tree Polylepis tarapacana occurs. Polylepis-dominated ecosystems are presently too scattered and reduced in Chile (Gosling et al. 2009) to be mapped in this analysis.

Overall, experts consulted agreed with the methods and the proposed classification of ecosystems, which was considered an advance over previous classifications of Chile's natural communities and floristic associations. Previous efforts had a strong emphasis on a single ecosystem component, the vascular flora. Experts also welcomed the distinction in 
this assessment of anthropogenic ecosystems, because of their accelerated growth in recent decades and the lack of systematic monitoring.

\section{Conservation scenarios}

In the analysis of the representation of the 30 ecosystems in the NSPA and NSPA plus PPA we identified 15 ecosystems lacking adequate protection in the NSPA and 11 ecosystems that lacked protection wen the areas of NSPA and PPA are considered together (Table 2). Two of the three different steppe ecosystems are not covered by NSPA, however when PPA is added, these three ecosystems reach the $17 \%$ goal.

Ecosystems dominated by succulents (Table 2) are extremely underrepresented in both scenarios (NSPA and NSPA+PPA), requiring urgent conservation actions. The same is true for ecosystems dominated by scrub and forests located in central Chile, with an extremely low cover of under protection $(<3 \%)$. With the exception of sclerophyllous forests and winter deciduous forests from central Chile, most forest ecosystems are well represented in the NSPA (predominantly $>17 \%$ ). Ecosystems under extreme conditions (high/low temperature), such as salt flats, sand dune ecosystems and deserts have a low protection in the NSPA. In spite of the large extension of desert in Chile, just a $2.1 \%$ is under protection (NSPA and PPA). Ecosystems such as lava flows, volcanic rocks and ash, glaciers and aquatic ecosystem are well represented in NSPA, because public protected areas are concentrated on Andean Montaintops and high latitudes (Table 2; Fig. 1).

\section{Discussion}

\section{Advantages of the proposed ecosystem classification criteria}

The integration of geographic information about units of land cover/land use, information on vegetation combined with functional criteria (Table 1), which is currently available and widely applicable for many countries, provides us with a new tool to identify terrestrial ecosystems more systematically (Table 2). Leaf traits offer insights into fundamental ecosystem processes, such as litter decomposition and nutrient recycling (Hättenschwiler et al. 2011), water and carbon fluxes (Poorter et al. 2009; Poorter and Kitajima 2007), and correlate well with the distribution of vegetation types across different climate zones of globe (Peppe et al. 2011; van Bodegom et al. 2014). On these grounds, the framework for ecosystem classification presented here can help us understand functional differences among land units that go beyond the species composition. An ecosystem framework allows the analysis of mechanistic connections between biodiversity and ecosystem processes and services (Hooper et al. 2012; Cardinale et al. 2012).

This ecosystem classification considers the scientific principles and practical recommendations discussed by Keith et al. (2013), which IUCN has put forward for future national assessments of ecosystem status. The proposed classification of ecosystems improves over existing schemes by integrating functional aspects of assessment units and avoiding taxonomic biases that hamper the progress towards a comprehensive system of public protected areas (Squeo et al. 2012; Jorquera-Jaramillo et al. 2012). Franklin (1993) argued that a focus on ecosystems has conceptual and practical advantages for conserving habitats and species, and for the design of conservation landscapes. In addition, the number of 30 ecosystems defined in this work is more easily applicable to conservation, ecosystem 
service assessments and long-term monitoring than schemes with a larger number of units. The high diversity of ecosystems found along the latitudinal extent and topographic gradients of Chile offer us an outstanding scenario for testing the applicability of the classification criteria proposed in this work.

Another advantage of the ecosystem classification proposed here is the integration into future ecosystem assessments of natural and anthropogenic land use/cover units. The latter are generally omitted from other schemes, which could be based on potential species distributions or climatic niches. Although alien flora and fauna largely dominate anthropogenic ecosystems, such as urban areas, it is important to assess the future growth of these ecosystems because of their condition of "sinks" for ecosystem services and large demands that they impose on the surrounding wild landscape (Alberti and Marzluff 2004). In addition, the recent literature suggests that some human-dominated landscapes, including farmland and urban areas, can be important reservoirs of remnant wildlife and can serve as conduits for dispersal among natural areas (Mendenhall et al. 2014; Aronson et al. 2014).

Rapidly expanding anthropogenic ecosystems (e.g., urban-industrial areas) and the extension of historically unprecedented combinations of native and exotic species or "novel" ecosystems should be inventoried and monitored because of their growing global dimension (Hobbs et al. 2006, 2009; Pauchard et al. 2006; DeFries et al. 2010). In the case of Chile, commercial forestry plantations, monocultures of eucalyptus and Pinus radiata that presently cover nearly 3 million hectares, often facilitate the expansion of exotics (Bustamante et al. 2003). They could also be considered novel ecosystems with their own powers of expansion (Simberloff et al. 2009). Forestry monocultures encroaching the biodiversity-richest area of the country (Armesto et al. 1998) will undoubtedly have major impacts on biodiversity and ecosystem functions.

The integration across spatial scales in the present classification facilitates the inclusion of ecosystems occupying small areas, associated with particular edaphic or topographic conditions. Although we were unable to map these ecosystems in the present assessment, they should be part of future ecosystem assessments. Ecosystems omitted from this work, such as high Andean peatlands (Squeo et al. 2006), riparian ecosystems, swamp forests, and fog-dependent ecosystems on coastal mountaintops (Del-Val et al. 2006) are all characterized by highly endemic biodiversity and fragility in the face of climate change.

According to Sala et al. (2000), Mediterranean and temperate ecosystems will continue to be highly threatened by land use change and human population growth in the present century, and should be especially sensitive to changing socio-economic scenarios. We show here that ecosystems located in Central Chile are extremely under represented in NSPA, even when PPAs were added. Private Protected Areas increased the representativeness of some ecosystems (Table 2), they presently remain unrecognized and are not legally protected, and have a high vulnerability to future land development and human disturbance. Ecosystems such as forests, glaciers and lava flows are well represented in NSPA, because of the high concentration the protected land at high elevation around Andean volcanoes, glaciers, and lakes. Future conservation efforts should prioritize the protection of biologically-rich Central Chilean $\left(30^{\circ}-40^{\circ} \mathrm{S}\right)$ ecosystems, especially sclerophyll scrublands and winter deciduous forests.

\section{Final remarks}

We introduce here the conceptual foundations and a methodology for a classification of terrestrial ecosystems that provides a useful baseline for future assessments of biodiversity 
and conservation status. We believe that the 30 ecosystems defined here for mainland Chile can be readily integrated to current national and regional accounting of natural areas, anthropogenic land use, and ecosystem service provision. We recommend that such assessments should be repeated with at least a decadal frequency. Our analysis reveals that about $50 \%$ of Chilean ecosystems are underrepresented in the Chilean NSPA, considering the $17 \%$ target for each ecosystem. A large national effort will be needed to achieve the $17 \%$ target defined by international agreements.

Additional data are needed on inconspicuous, often neglected, but functionally relevant components of many terrestrial ecosystems (from deserts to forests), such as cryptogamic covers (mosses, liverworts, lichens), which have significant roles as $\mathrm{N}$ fixers and carbon dioxide assimilators at both regional and global scales (Elbert et al. 2012). Our knowledge of such biotic components of ecosystems is currently limited, but an ecosystem approach will be useful to underscore the functional role of these groups of organisms.

Acknowledgements Research funded by a Grant from the Chilean Ministry of the Environment to the Institute of Ecology and Biodiversity. Additional support came from the Millennium Scientific Initiative (Grant P05-002) and from CONICYT, Chile (Grant PFB-23).

Open Access This article is distributed under the terms of the Creative Commons Attribution 4.0 International License (http://creativecommons.org/licenses/by/4.0/), which permits unrestricted use, distribution, and reproduction in any medium, provided you give appropriate credit to the original author(s) and the source, provide a link to the Creative Commons license, and indicate if changes were made.

\section{References}

Acosta A, Carranza ML, Giancola M (2005) Landscape change and ecosystem classification in a municipal district of a small city (Isernia, Central Italy). Env Monit Assess 108:323-335

Alberti M, Marzluff JM (2004) Ecological resilience in urban ecosystems: linking urban patterns to human and ecological functions. Urban Ecosystems 7:241-265

Armesto JJ, Rozzi R, Smith-Ramírez C, Arroyo MK (1998) Conservation targets in South American temperate forests. Science 279:1271-1272

Armesto JJ, Arroyo MTK, Hinojosa LF (2007) The Mediterranean Environment. In: Veblen TT, Young KR, Orme AR (eds) The physical geography of South America. Oxford University Press, Oxford, pp 184-199

Armesto JJ, Carmona M, Smith-Ramírez C, Celis-Diez JL, Díaz I, Gaxiola A, Gutiérrez AC, Núñez-Ávila M, Pérez C, Rozzi R (2009) Old-growth temperate rain forests of South America: conservation, plantanimal interactions, and baseline biogeochemical processes. Old-growth forests: function, fate and value. In: Wirth C, Gleixner G, Heimann M (eds) Ecological studies, vol 207. Springer, Heidelberg, pp 367-390

Armesto JJ, Manuscevich D, Mora A, Smith-Ramírez C, Rozzi R, Abarzúa AM, Marquet PA (2010) From the holocene to the anthropocene: a historical framework for land cover change in southwestern South America in the past 15,000 years. Land Use Policy 27:148-160

Aronson MF, La Sorte FA, Nilon CH, Katti M, Goddard MA, Lepczyk CA et al (2014) A global analysis of the impacts of urbanization on bird and plant diversity reveals key anthropogenic drivers. Proc R Soc B 281:20133330. doi:10.1098/rspb.2013.3330

Arroyo MTK, Squeo FA, Armesto JJ, Villagrán C (1988) Effects of aridity on plant diversity on the northern Chilean Andes: results of a natural experiment. Ann Mo Bot Gard 75:55-78

Arroyo MTK, Armesto JJ, Squeo FA, Gutiérrez JR (1993) Global change: the flora and vegetation of Chile. In: Mooney HA, Fuentes ER, Kronberg BI (eds) Earth system responses to global change. Contrasts between North and South America. Academic Press, New York, pp 239-263

Austin AT, Vivanco L (2006) Plant litter decomposition in a semi-arid ecosystem controlled by photodegradation. Nature 442:555-558

Benson JS (2006) New South Wales Vegetation Classification and Assessment: introduction-the classification, database, assessment of protected areas, and threat status of plant communities. Cunninghamia 9:331-382 
Bustamante RO, Serey I, Pickett STA (2003) Forest fragmentation, plant regeneration and invasion processes across edges in Central Chile. In: Bradshaw G, Marquet P (eds) How landscapes change. Human disturbance and ecosystem fragmentation in the Americas. Springer, New York, pp 145-160

Cardinale B, Duffy E, Gonzalez A, Hooper D, Perrings C, Venail P et al (2012) Biodiversity loss and its impact on humanity. Nature 486:59-67

CBD (2010) Strategic plan for biodiversity 2011-2020. Provisional technical rationale, possible indicators and suggested milestones for the Aichi biodiversity targets. Note by the Executive Secretary. Convention on Biological Diversity, Nagoya

Chapin FS, Bret-Harte MS, Hobbie SE, Zhong H (1996) Plant functional types as predictors of transient responses of arctic vegetation to global change. J Veg Sci 7(3):347-358

Chapin FS, Matson PA, Vitousek PM (2012) Principles of terrestrial ecosystem ecology. Springer, New York

Cohen MJ, Creed IF, Alexander L et al (2016) Do geographically isolated wetlands influence landscape functions? Proc Natl Acad Sci USA. doi:10.1073/pnas.1512650113

Comer P, Faber-Langendoen D, Evans R, Gawler S, Josse C, Kittel G et al (2003) Ecological systems of the United States: a working classification of US terrestrial systems. NatureServe, Arlington, Virginia

CONAF, CONAMA, BIRF, UACh, PUC, UCT (1999) Catastro y Evaluación de los Recursos Vegetacionales Nativos de Chile. Informe Nacional con Variables Ambientales, Santiago, Chile

CONAMA (2005) Plan de Acción de País para la Implementación de la Estrategia Nacional de Biodiversidad 2004-2015. Comisión Nacional del Medio Ambiente, Santiago, Chile

Corlett R (2015) The Anthropocene concept in ecology and conservation. Trends Ecol Evol 30:36-41

Cowling RM, Pressey RL, Rouget M, Lombard AT (2003) A conservation plan for a global biodiversity hotspot-the Cape Floristic Region, South Africa. Biol Conserv 112:191-216

Cowling RM, Ojeda F, Lamont BB, Rundel PW, Lechmere-Oertel R (2005) Rainfall reliability, a neglected factor in explaining convergence and divergence of plant traits in fire-prone Mediterranean-climate ecosystems. Glob Ecol Biogeogr 14:509-519

Cuevas J (2000) Tree recruitment at the Nothofagus pumilio Alpine timberline in Tierra del Fuego, Chile. J Ecol 88:840-855

Currie WS (2011) Units of nature or processes across scales? The ecosystem concept at age 75. New Phytol 190(1):21-34

DeFries RS, Rudel T, Uriarte M, Hansen M (2010) Deforestation driven by urban population growth and agricultural trade in the 21st century. Nat Geosci 3:178-181

Del-Val E, Armesto JJ, Barbosa O, Christie DA, Gutiérrez AG, Jones CG, Weathers KC (2006) Rain forest islands in the Chilean semiarid region: fog-dependency, ecosystem persistence and tree regeneration. Ecosystems 9(4):598-608

Devillers P, Devillers-Terschuren J (1996) A classification of South American habitats. Report. Institute of Terrestrial Ecology, Institut Royal des Sciences Naturelles de Belgique, Belgium

Devillers P, Devillers-Terschuren J, Ledant J-P (1991) CORINE biotopes manual habitats of the European community data specifications-Part 2. Commission of the European Communities, Luxembourg

Díaz S, Cabido M (1997) Plant functional types and ecosystem function in relation to global change. J Veg Sci 8(4):463-474

Díaz IA, Sieving KE, Pena-Foxon ME, Larrain J, Armesto JJ (2010) Epiphyte diversity and biomass loads of canopy emergent trees in Chilean temperate rain forests: a neglected functional component. For Ecol Manag 259:1490-1501

Dirzo R, Young H, Galetti M, Ceballos G, Isaac N, Collen B (2014) Defaunation in the Anthropocene. Science 345:401-406

Duckworth JC, Kent M, Ramsay PM (2000) Plant functional types: an alternative to taxonomic plant community description in biogeography? Prog Phys Geog 24(4):515-542

EEA (2006) Land accounts for Europe 1990-2000. Towards integrated land and ecosystem accounting, EEA Report

Elbert W, Weber B, Burrows S, Steinkamp J, Büdel B, Andreae M et al (2012) Contribution of cryptogamic covers to the global cycles of carbon and nitrogen. Nat Geosci 5:459-462

Etienne M, Prado C (1982) Descripción de la vegetación mediante la cartografía de ocupación de tierras, Conceptos y Manual de uso práctico. Universidad de Chile, UNESCO, MAG Ciencias Agrícolas, Chile

Franklin JF (1993) Preserving biodiversity: species, ecosystems, or landscapes? Ecol Appl 3:202-205

Gajardo R (1994) La Vegetación Natural de Chile. Clasificación y distribución geográfica. Editorial Universitaria, Santiago, Chile

Gayó EM, Latorre C, Jordan TE, Nester PL, Estay SA, Ojeda KF, Santoro CM (2012) Late quaternary hydrological and ecological changes in the hyperarid core of the northern Atacama Desert $\left(21^{\circ} \mathrm{S}\right)$. Earth Sci Rev 113:120-140 
Gosling WD, Hanselman JA, Knox C, Valencia BG, Bush MB (2009) Long-term drivers of change in Polylepis woodland distribution in the central Andes. J Veg Sci 20:1041-1052

Hassan R, Scholes R, Ash N (eds) (2005) Ecosystems and human well-being: current state and trends, vol 1. Island Press, Washington, DC

Hättenschwiler S, Coq S, Barantal S, Handa I (2011) Leaf traits and decomposition in tropical rainforests: revisiting some commonly held views and towards a new hypothesis. New Phytol 189:950-965

Hildebrand-Vogel R, Godoy R, Vogel A (1990) Subantartic-Andean Nothofagus pumilio forests. Vegetatio 89:55-68

Hobbs RJ, Arico S, Aronson J, Baron JS, Bridgewater P, Cramer VA et al (2006) Novel ecosystems: theoretical and management aspects of the new ecological world order. Global Ecol Biogeogr 15(1):1-7

Hobbs RJ, Higgs E, Harris JA (2009) Novel ecosystems: implications for conservation and restoration. Trends Ecol Evol 24(11):599-605

Holmgren M, Aviles R, Sierralta L, Segura AM, Fuentes ER (2000) Why have European herbs so successfully invaded the Chilean matorral? Effects of herbivory, soil nutrients, and fire. J Arid Environ 44:197-211

Hooper DU, Adair EC, Cardinale BJ, Byrnes JE, Hungate BA, Matulich KL et al (2012) A global synthesis reveals biodiversity loss as a major driver of ecosystem change. Nature 486:105-108

Jorquera-Jaramillo C, Alonso-Vega JM, Aburto J, Martínez-Tillería K, León MF, Pérez MA, Gaymer DF, Squeo FA (2012) Conservación de la biodiversidad en Chile: nuevos desafíos y oportunidades en ecosistemas terrestres y marinos costeros. Revista Chilena de Historia Natural 85:267-280

Josse C, Navarro G, Encarnación F, Tovar A, Comer P, Ferreira W et al (2007) Sistemas Ecológicos de la Cuenca Amazónica de Perú y Bolivia. Clasificación y mapeo. NatureServe, Arlington, Virginia

Kattge J, Díaz S, Lavorel S, Prentice I, Leadley P, Bönisch G et al (2011) TRY — a global database of plant traits. Glob Change Biol 17:2905-2935

Keith DA, Rodríguez JP, Rodríguez-Clark KM, Nicholson E, Aapala K, Alonso A et al (2013) Scientific foundations for an IUCN red list of ecosystems. PLoS ONE 8(5):e62111. doi:10.1371/journal.pone. 0062111

Kujala H, Moilanen A, Araújo MB, Cabeza M (2013) Conservation planning with uncertain climate change projections. PLoS ONE 8(2):e53315. doi:10.1371/journal.pone.0053315

Lara A, Little C, Urrutia R, McPhee J, Álvarez-Garretón C, Oyarzún C et al (2009) Assessment of ecosystem services as an opportunity for the conservation and management of native forests in Chile. For Ecol Manag 258:415-424

Luebert F, Pliscoff P (2006) Sinopsis Climática y Vegetacional de Chile. Editorial Universitaria, Santiago, Chile

Meidinger D, Pojar J (1991) Ecosystems of British Columbia. Ministry of Forests, Victoria

Mendenhall CD, Karp DS, Meyer CFJ, Hadly EA, Daily GC (2014) Predicting biodiversity change and averting collapse in agricultural landscapes. Nature 509:213-217

Mucina L (2013) Ecosystems of Europe. In: Levin SA (ed) Encyclopedia of biodiversity, vol 3, 2nd edn. Academic Press, Waltham, MA, pp 333-346

Myers N, Mittermeie RA, Mittermeier CG (2000) Biodiversity hotspots for conservation priorities. Nature 403:453-458

NatureServe (2003) Ecological Systems of Latin American and the Caribbean Database, version 1.01. NatureServe. Arlington, VA. http://www.natureserve.org/conservation-tools/standards-methods/ ecological-systems-latin-america-and-caribbean

Noble R, Dirzo R (1997) Forests as human-dominated ecosystems. Science 277:522-525

Núñez-Ávila M, Corcuera E (2014) A comprehensive characterization of Private Conservation Initiatives in Chile. In: Solton Sue, Redford Kent, Dudley Nigel (eds) PPA futures: assessing and advancing the role of privately protected areas. IUCN, Switzerland

Pauchard A, Aguayo M, Peña E, Urrutia R (2006) Multiple effects of urbanization on the biodiversity of developing countries: the case of a fast-growing metropolitan area (Concepción, Chile). Biol Cons 127:272-281

Peppe DJ, Royer DL, Cariglino B, Oliver SY, Newman S, Leight E et al (2011) Sensitivity of leaf size and shape to climate: global patterns and paleoclimatic applications. New Phytol 190:724-739

Pérez CA, Hedin LO, Armesto JJ (1998) Nitrogen mineralization in two unpolluted old-growth forests of contrasting biodiversity and dynamics. Ecosystems 1:361-373

Pisano E (1974) Estudio ecológico de la región continental sur del área andino-patagónica. II. Contribución a la fitogeografía de la zona del parque Nacional Torres del Paine. Anales Instituto Patagonia 5(1-2):59-104 
Poorter L, Kitajima K (2007) Carbohydrate storage and light requirements of tropical moist and dry forest tree species. Ecology 88:1000-1011

Poorter H, Niinemets U, Poorter L, Wright IJ, Villar R (2009) Causes and consequences of variation in leaf mass per area (LMA): a meta-analysis. New Phytol 182:565-588

Poulter B, Frank D, Ciais P et al (2014) Contribution of semi-arid ecosystems to interannual variability of the global carbon cycle. Nature 509:600-603. doi:10.1038/nature13376

Ramos-Jiliberto R, Albornoz AA, Valdovinos FS, Smith-Ramírez C, Arim M, Armesto JJ, Marquet PA (2009) A network analysis of plant-pollinator interactions in southern rain forests of Chiloé Island, Chile. Oecologia 160:697-706

Rundel P (1981) The matorral zone on central Chile. In: di Castri F, Goodall DW, Specht RL (eds) Mediterranean-type shrublands. Elsevier, Amsterdam, pp 175-201

Sala OE, Chapin FS, Armesto JJ, Berlow E, Bloomfield J, Dirzo R et al (2000) Global biodiversity scenarios for the year 2100. Science 287:1770-1774

Scheffer M (2009) Critical transitions in nature and society. Princeton University Press, Princeton

Schulz JJ, Cayuela L, Echeverría C, Salas J, Rey JM (2010) Monitoring land cover change of the dryland forest landscape of central Chile (1975-2008). Appl Geogr 30:436-447

Simberloff M Núñez, Ledgard N, Pauchard A, Richardson D, Sarasola M et al (2009) Spread and impact of introduced conifers in South America: lessons from other southern hemisphere regions. Austral Ecol 35(5):489-504

Smith-Ramírez C (1996) Algunos usos indígenas tradicionales de la flora del bosque templado. In: Armesto JJ, Villagrán C, Arroyo MTK (eds) Ecología de los Bosques Nativos de Chile. Editorial Universitaria, Santiago, pp 389-404

Smith-Ramírez C, Martínez P, Núñez M, González C, Armesto JJ (2005) Diversity, flower visitation frequency and generalism of pollinators in temperate rain forests of Chiloé Island, Chile. Bot J Linn Soc 147:399-416

Speziale KL, Ruggiero A, Ezcurra C (2010) Plant species richness-environment relationships across the Subantarctic-Patagonian transition zone. J Biogeogr 37:449-464

Squeo FA, Arancio G, Cavieres L, Gutiérrez JR, Muñoz M, Marticorena C (2001) Análisis del estado de conservación de la flora nativa de la IV Región de Coquimbo. In: Squeo FA, Arancio G, Gutiérrez JR (eds) Libro Rojo de la Flora Nativa de la Región de Coquimbo y de los Sitios Prioritarios para su Conservación. Ediciones de la Universidad de La Serena, La Serena, pp 53-62

Squeo FA, Belmonte E, Arancio G, León M, Kalin-Arroyo MT, Becerra P (2003) Informe Final Clasificación revisada de los ecosistemas terrestres del país y sus prioridades de conservación. Departamento de Biología, Universidad de La Serena, La Serena, Chile

Squeo FA, Warner BG, Aravena R, Espinoza D (2006) Bofedales: high altitude peatlands of the central Andes. Rev Chil Hist Nat 79:245-255

Squeo FA, Arancio G, Letelier L, Marticorena A, Muñoz-Schick M, León-Lobos P, Arroyo MTK (2008) Estado de Conservación de la Flora Nativa de la Región de Atacama. In: Squeo FA, Arancio G, Gutiérrez JR (eds) Libro Rojo de la Flora Nativa y de los Sitios Prioritarios para su conservación: Región de Atacama. Ediciones Universidad de La Serena, La Serena, pp 45-59

Squeo FA, Estévez RA, Stoll A, Gaymer CF, Letelier L, Sierralta L (2012) Towards the creation of an integrated system of protected areas in Chile: achievements and challenges. Plant Ecol Divers $5(2): 233-243$

Steffen W, Grinevald J, Crutzen P, McNeill J (2011) The Anthropocene: conceptual and historical perspectives. Philos Trans A 369:842-867

Traill LW, Lim MLM, Sodhi NS, Bradshaw CJA (2010) Mechanisms driving change: altered species interactions and ecosystem function through global warming. J Anim Ecol 79(5):937-947

Van Bodegom PM, Douma JC, Verheijen LM (2014) A fully traits-based approach to modeling global vegetation distribution. Proc Natl Acad Sci USA 111:13733-13738

Van Sickle J, Hughes R (2000) Classification strengths of ecoregions, catchments, and geographic clusters for aquatic vertebrates in Oregon. J N Am Benthol Soc 19:370-384

Veblen T, Burns B, Kitzberger T, Lara A, Villalba R (1995) The ecology of the conifers of southern South America. In: Enright N, Hill R (eds) Ecology of the Southern Conifers. Melbourne University Press, Australia, pp 120-155

Vitousek P, Aber J, Howarth R, Likens G, Matson P, Schindler P, Schlesinger W, Tilman D (1997) Human alteration of the global nitrogen cycle: sources and consequences. Ecol Appl 7(3):737-750

Vörösmarty CJ, Sahagian D (2000) Anthropogenic disturbance of the terrestrial water cycle. Bioscience 50(9):753-765

Wearn OR, Reuman DC, Ewers RM (2012) Extinction debt and windows of conservation opportunity in the Brazilian Amazon. Science 337:228-232 
Wheeler BD (1999) Water and plants in freshwater wetlands. In: Baird A, Wilby RL (eds) Eco-hydrology: plants and water in terrestrial and aquatic environments. Routledge, London, UK, pp 127-180

Wheeler BD, Proctor MCF (2000) Ecological gradients, subdivisions and terminology of north-west European mires. J Ecol 88(2):187-203

Wilson KA, McBride MF, Bode M, Possingham HP (2006) Prioritizing global conservation efforts. Nature 440:337-340

Zhao Y, Feng D, Yua L, Wang X, Chen Y, Hernández HJ, Galleguillos M, Estades C, Biging G, Radke J, Gong P (2016) Detailed dynamic land cover mapping of Chile: accuracy improvement by integrating multi-seasonal land cover data. Remote Sens Environ 183:170-185 